\title{
Osteoblastoma of the Cervical Spine: A Case Report
}

\author{
Servikal Omurga Osteoblastomu: Olgu Sunumu
}

Melih Bozkurt ${ }^{1}$, Mevci Özdemir², Gökmen Kahiloğulları', Nihat Egemen ${ }^{1}$

${ }^{1}$ Ankara Üniversitesi Tip Fakültesi Beyin ve Sinir Cerrahi Ana Bilim Dalı ${ }^{2}$ Ergani Devlet Hastanesi, Beyin ve Sinir Cerrahi Kliniği
Received: 26.09.2010 - Accepted: 25.10.2010

Corresponding author

Uz.Dr. Mevci Özdemir

Ergani Devlet Hastanesi, Beyin ve Sinir Cerrahi Kliniği

Phone : : $\quad$ 904126115020

Fax $\quad:+904126115765$

Gsm : : $\quad: 905326253563$

E-mail Address : drmevci@hotmail.com

Osteoblastoma of the cervical spine extending from the C4 vertebral body to the paraspinal area is reported. Clinical, radiological and histological characteristics of the lesion are presented. The tumor's location, extension to the paraspinal area and response of the adjacent soft tissues are discussed.

Key Words : Osteoblastoma, Cervical Spine, Bone Tumor

Bu yazıda dördüncü servikal vertebradan paraspinal alana uzanım gösteren bir osteoblastoma olgusu sunulmuştur. Osteblastomanın klinik, radyolojik, histolojik özellikleri, tümörün paraspinal alana uzanımı ve yumuşak doku cevabı tartışılmıştır.

Anahtar Sözcükler: Osteoblastoma, Servikal Omurga, Kemik Tümörü

Osteoid-osteomas and osteoblastomas are solitary bone tumors, described by Jaffe and Lichtenstein $(1,2)$. Occasionally located in long bones, they account for less than $1 \%$ of all bone tumors. The spine is involved in $10 \%$ of the cases, and frequently the posterior elements of the thoracic and lumbar regions $(3,4,5)$. Males are affected more frequently (2.5 to 1 ), and the disease usually presents in the second decade (6). This case is presented because of its rarity and localization in the cervical spine.

\section{Case Report}

A 13-year-old girl was admitted to the hospital for investigation of spasmodic torticollis and disabling neck pain for 13 months. There was no history of prior trauma or any other disease. On physical examination, a mild spasmodic torticollis was found. Neurological examination was normal. Blood chemistry and cervical $\mathrm{X}$-ray were normal. Computerized tomography (CT) demonstrated a lesion from the left side of the $\mathrm{C} 4$ vertebral body, with sclerosis band and inhomogeneous matrix ossification (Figure 1a). T2-weighted magnetic resonance imaging (MRI) revealed hyperintense mass with reactive hyperintense signal in the paraspinal muscles (Figure 1b). Sagittal reconstruction CT revealed a bony lesion of the C4 vertebral body (Figure 1c). Digital substraction angiography (DSA) revealed compression of the left vertebral artery and flushing of the lesion (Figure 1d).

Left-sided anterior approach was chosen for the lesion. An oblique incision was used in front of the sternocleidomastoid muscle. Left common carotid artery, internal jugular vein, and vagal and phrenic nerves were exposed. The esophagus, trachea and common carotid artery left in the medial and sternocleidomastoid muscle left in the lateral side. Longus colli muscles were stony and rough. C3-4-5 vertebral bodies were exposed. The lesion was found to originate from the vertebral body in front of the transverse foramen of C4. The tumor was removed totally with curette. The lesion was extremely vascular. Muscle biopsies were taken. Stabilization and fusion procedures were not needed. Pathologic examination revealed osteoblastoma and 
inflammatory reaction and atrophy of the muscles (Figure 2). Neck pain and spasmodic torticollis resolved after surgery. There were no neurological deficits, and postoperative CT revealed total excision (Figure 3).

\section{Discussion}

Osteoblastoma accounts for approximately $3 \%$ of benign and $1 \%$ of all primary bone tumors (7). The spine is the most frequently affected, accounting for about 30\%-40\% (4). Osteoblastoma occurs predominately during the first two decades, in accordance with our case. They occasionally originate in the posterior vertebral elements, especially in the spinous processes and laminae $(6,8)$. While involvement of the vertebral body is frequent, osteoblastoma originating only in the vertebral body is rare (9). In our case, the tumor originated from the left side of the vertebral body in front of the transverse foramen of $\mathrm{C} 4$ and extended to the paraspinal area.

Presenting symptoms with osteoblastoma of the spine are localized, increasing pain, as in this case $(4,5,6)$. Nonspecificity of symptoms was neglected by the physician, contributing to the delay in diagnosis for 13 months. Neurological deficit was not seen in our patient because of the extension of the tumor to the paraspinal area.

The lesions appear lytic and expansive on plain radiographs (7). Matrix mineralization occurs in nearly $55 \%$ to $72 \%$ of the cases $(6,7)$. Computerize tomography is generally informative about the lesion. Magnetic resonance imaging can provide additional information regarding the spinal cord and nerve root and neighboring soft tissue reaction (10).

Osteoblastomas involving the adjacent soft tissues have been identified (11). In the case presented, the adjacent soft tissue reaction was clearly seen (Figure $1 b)$.

Treatment of cervical spine osteoblastoma

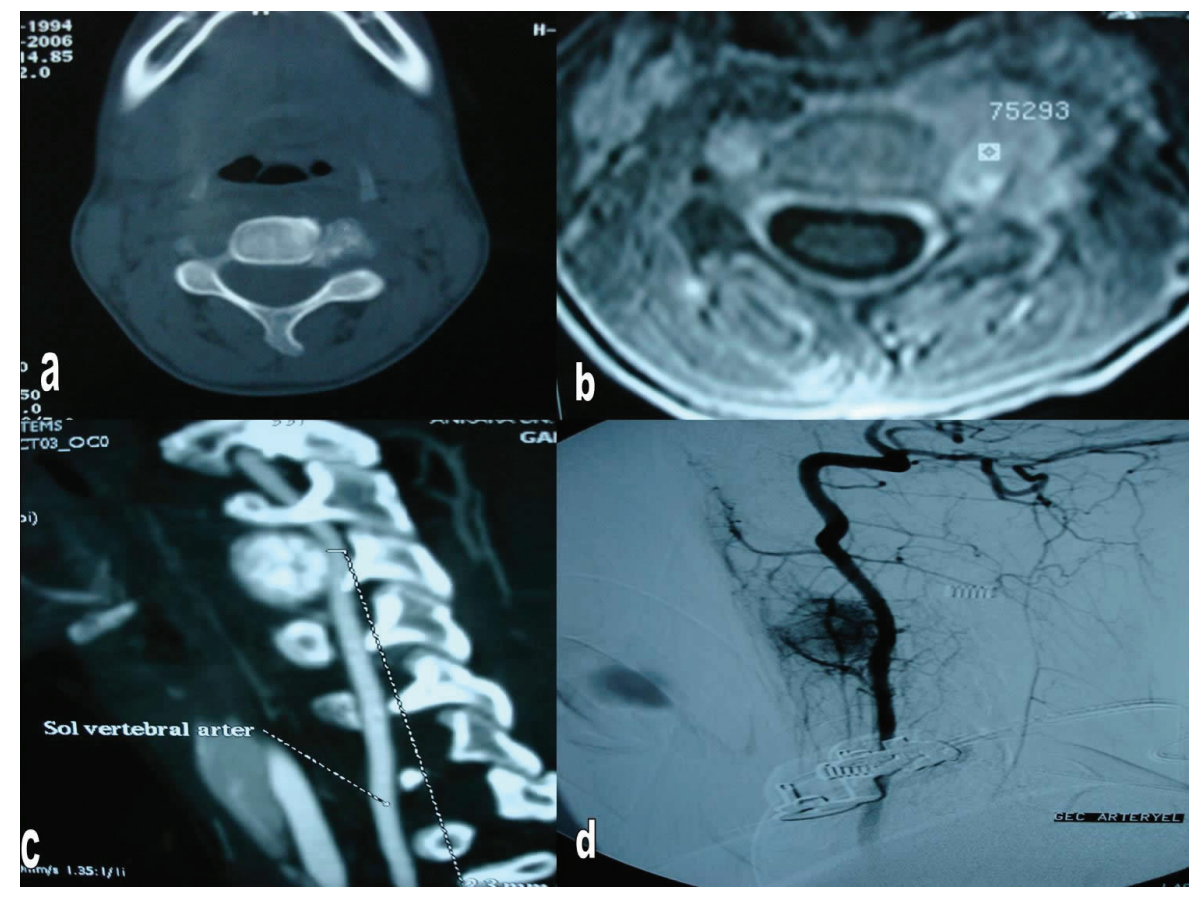

Figure 1a: Axial CT showing lesion from the left side of the C4 vertebral body.

Figure 1b: T2-MRI showing hyperintense mass with reactive hyperintense signal in the muscles. Figure 1c: Sagittal reconstruction CT of the lesion.

Figure 1d: DSA revealing the compression of the artery.

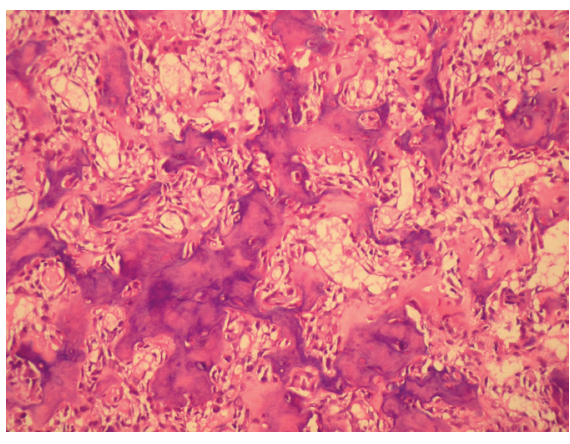

Figure 2: Pathology images (hematoxylin and eosin: osteoblastoma)

requires a complete surgical resection (12). The type of surgical approach and necessity for stabilization and fusion procedures must be considered individually in each patient. Treatment choice in recurrent osteoblastoma is reexcision (13). Radiation therapy may sometimes be considered as an adjuvant therapy (14).

\section{Conclusion}

We report a rare case of osteoblastoma originating from the vertebral body in front of the transverse foramen of C4 with severe vertebral artery compression. The patient was successfully treated by total excision of the tumor.

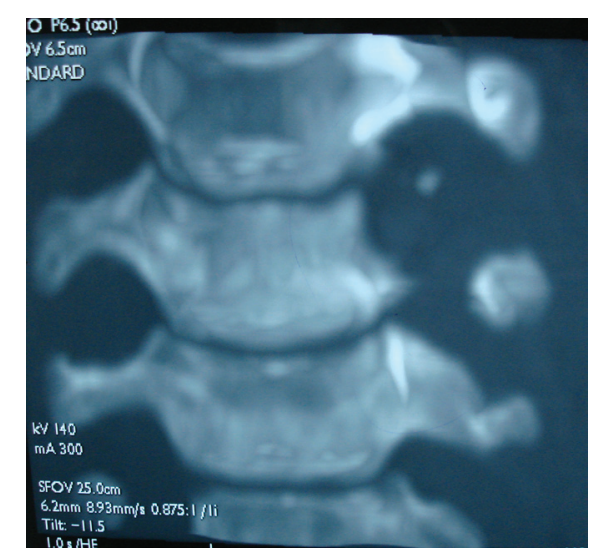

Figure 3: Postoperative 3D reconstruction CT showing total excision. 


\section{REFERENCES}

1. Jaffe HL. "Osteoid-osteoma": A benign osteoblastic tumor composed of osteoid and atypical bone. Arch Surg 1935; 31:70928.

2. Lichtenstein L. Benign osteoblastoma: a category of osteoid and bone forming tumors other than classical osteoid-osteoma, which may be mistaken for giant-cell tumor or osteogenic sarcoma. Cancer 1956; 9:1044-52.

3. Azouz EM, Kozlowski K, Marton D, et al. Osteoid-osteoma and osteoblastoma of the spine in children. Report of 22 cases with brief literature review. Pediatr Radiol 1986; 16:25-31.

4. Myles ST, MacRae ME. Benign osteoblastoma of the spine in childhood. J Neurosurg 1988; 68:884-8.

5. Zileli M, Cagli S, Basdemir G, Ersahin Y. Osteoid osteomas and osteoblastomas of the spine. Neurosurg Focus. 2003 Nov 15; 15(5):E5.
6. Nemoto O, Moser RP, Van Dam BE, et al. Osteoblastoma of the spine: review of 75 cases. Spine 1990; 15:1272-80.

7. Lucas DR, Unni KK, McLeod RA, et al. Osteoblastoma: clinico-pathologic study of 306 cases. Hum Pathol 1994; 25:11734.

8. Healey JH, Ghelman B. Osteoid-osteoma and osteoblastoma: current concepts and recent advances. Clin Orthop 1986; 204:76-85.

9. Syklawer R, Osborn RE, Kerber CW, et al. MRI of vertebral osteoblastoma: report of two cases. Surg Neurol 1990; 34:421-6.

10. Ertug O, Ugur E, Bilge C, et al. CT and MR imaging of vertebral osteoblastoma report of two cases. Clin Imaging 1996; 20:37-41.

11. Raskas DS, Graziano GP, Herzenberg JE, Heidelberger KP, Hensinger RN. Osteoidosteoma and osteoblastoma of the spine. J Spinal Disord. 1992; 5:204-11.
12. Moore T, McLain RF. Image-guided surgery in resection of benign cervicothoracic spinal tumors: report of two cases. Spine J 2005; 5:109-14.

13. Ozaki T, Liljenqvist U, Hillmann A, et al. Osteoid-osteoma and osteoblastoma of the spine: experiences with 22 patients. Clin Orthop 2002; 397:394- 402.

14. Shikata J, Yamamuro T, Hiokazu I, et al. Benign osteoblastoma of the cervical spine: a review of 75 cases. Surg Neurol 1987; 27:381-5. 